\title{
Functional similarity and dissimilarity facilitate alien plant invasiveness along biotic and abiotic gradients in an arid protected area
}

\author{
Reham F. El-Barougy (D) Ibrahim Elgamal • Rudolf P. Rohr • Anna F. Probert • \\ Abdel-hamid A. Khedr - Sven Bacher
}

\begin{abstract}
Two contradictory hypotheses have been put forth to forecast alien invasiveness: being either functionally similar, or dissimilar, to resident natives along environmental gradients. The 'try-harder' hypothesis predicts that alien plants will be functionally dissimilar to natives and should thus exhibit exaggerated trait values when compared to natives in respect to resource extraction or stress tolerance. In contrast, the 'join-the-locals' hypothesis, which is compatible with "environmental filtering", predicts functional similarities among alien and native species in richer, but not in resource-limited environments. Here, we propose a framework that links the successful alien plant strategy, i.e. being functionally similar or dissimilar to natives, to the harshness of the environment and the availability of resources. We tested these two hypotheses using a trait-environment dataset of 33 alien and 130 native plants in 96 sites covering a gradient of soil resources (organic matter,
\end{abstract}

R. F. El-Barougy $(\bowtie)$. A. A. Khedr

Department of Botany and Microbiology, Faculty of Science, Damietta University, New Damietta, Egypt e-mail: Reham_Fekry2012@du.edu.eg;

reham.elbarougy@unifr.ch

R. F. El-Barougy · R. P. Rohr · A. F. Probert · S. Bacher Department of Biology, University of Fribourg, Avenue de l'Europe 20, 1700 Fribourg, Switzerland

I. Elgamal

Nature Conservation Sector, Egyptian Environmental Affairs Agency, Cairo 11728, Egypt nitrogen, soil moisture) in Saint-Katherine, an arid protected area in Egypt. We estimated 18 interaction coefficients between three candidate traits (specific leaf area, above-ground biomass, height) of alien and native plants as well as soil resources using linear mixed-effects models. Additionally, we calculated the mean and the hierarchical functional distance among aliens and natives along soil gradients. Our results revealed that in extreme resource-limited environments, aliens and natives were functionally similar and had relatively equal trait values consistent with environmental filtering, thus supporting the 'join-thelocals' hypothesis. However, in environments richer in resources, aliens and natives were functionally dissimilar with aliens exhibiting more exploitative trait values (taller, higher SLA and biomass) than natives, providing support for the 'try-harder' hypothesis. While demonstrated in only one arid system, results suggest that linking soil resource availability with functional divergence and convergence among native and alien plants could be used as an informative strategy to predict alien invasiveness. Hence, future studies should investigate the functional response of alien and native plants in different environments against different resource gradients to test for the generality of the patterns we found.

Keywords Functional traits · Competition · Environmental filtering $\cdot$ Soil gradients 


\section{Introduction}

In recent decades, the comparative analysis of differences in the functional traits of alien and native plant species has expanded drastically in the context of plant invasion ecology (Pyšek and Richardson 2007; Tecco et al. 2010, 2013). Differences in the traits of native and alien plants have been proposed as a proxy to explain alien invasiveness in natural ecosystems (Funk et al. 2008; Leffler et al. 2014). This approach has often been used to examine trait variation across environmental gradients between alien and native plant species and investigate which traits facilitate aliens over resident natives to predict invasiveness (Funk and Vitousek 2007; Leishman et al. 2010; van Kleunen et al. 2010; Heberling and Fridley 2013). However, such an approach neglects the differences between alien and native species based on their functional relatedness and their functional responses along soil resource gradients.

How traits between alien and native plants vary with resource availability has been studied comparatively in high- versus low-resource conditions (Leishman and Thomson 2005; Funk and Vitousek 2007; González et al. 2010; Leishman et al. 2010). It has been proposed that aliens have the potential to outperform resident natives in nutrient-rich areas through the exploitation of resources unused by natives (Davis et al. 2000; Daehler 2003) and/or a reduction in herbivory/parasitism rates (Blumenthal 2005, 2006) or an evolution of high competitive abilities (Blossey and Notzold 1995). On the other hand, under limiting resource conditions, natives are predicted to outperform aliens due to the development of strategies that enable them to tolerate higher levels of stress through the extraction of limiting resources (however, for explanations of alien success in lowresource environments see Funk and Vitousek 2007; González et al. 2010).

Many hypotheses have been put forth to link alien invasiveness with being similar or dissimilar to natives, to the harshness of the environment, and the availability of resources. The 'try-harder' hypothesis, initially proposed by Crawley et al. (1996), states that successful aliens should be able to utilize local resources better than resident native species. According to this concept, aliens are functionally dissimilar from native species because they exhibit more conservative functional trait syndromes (e.g. low height values and small leaves, with low specific area) in extreme limiting resources environments (Leishman and Thomson 2005; Rejmánek et al. 2005; Burns 2006; Pyšek and Richardson 2007; Funk and Vitousek 2007) and more exploitative syndromes (e.g. high height values and large leaves, with high specific area) in resource-rich environments (Leishman et al. 2008; Tecco et al. 2010, 2013; Dyderski and Jagodziński 2019). This dissimilarity may arise as a consequence of competitive exclusion (MacDougall et al. 2009; Mayfield and Levine 2010; Li et al. 2015), which eliminates alien species that are too similar in their trait values (Macarthur and Levins 1967; Abrams 1983; Davies 2006). Under this hypothesis, an alien species' position in a competitive hierarchy is attributed to the differences in its functional trait values compared with resident natives. Within invaded communities, this concept has been suggested to explain invasion success due to the link between a species functional traits and competitive ability to acquire resources (Westoby et al. 2002; Gallien et al. 2017). For example, alien plants that grow taller (i.e. with a positive hierarchical value) than resident natives are usually expected to invade natural communities and outcompete resident natives (Conti et al. 2018).

In contrast, the 'join-the-locals' hypothesis proposes that a pattern of aliens co-occurring with functionally similar natives is expected due to the strong effect of environmental filtering (environmental conditions that select for species capable of surviving and reproducing in a given locale (Cadotte et al. 2018). This pattern has been attributed to the selection of alien species that are able to exploit similar resources and tolerate the same environmental stressors as natives and subsequently have similar traits (Funk et al. 2016). Eventually, alien species are presumed to occupy a portion of the functional space originally occupied by native species, leading to an increased functional similarity between both species' groups (Kembel and Hubbell 2006; Catford et al. 2009). Likewise, there is some support that alien and native species have similar trait values and share limited resources (Daehler 2001; Duncan and Williams 2002; Maitner et al. 2012; Allen et al. 2013; Park and Potter 2015).

This study aimed to (a) investigate whether alien and native plants are functionally similar or dissimilar in terms of three key traits (height, specific leaf area 
SLA and biomass production) along a soil resource gradient and (b) determine which ecological process (environmental filtering/competitive exclusion) is driving the invasiveness of alien plant species along a soil resource gradient. We predicted that in environments with limited soil resources, alien and native plants would be functionally more similar (in terms of height, SLA and biomass), indicating similar competitive ability, due to the effect of environmental filtering ('join-the-locals' hypothesis). We also predicted that in resource-rich environments, alien plant species would be functionally dissimilar to natives and more competitive than resident natives due to competitive exclusion between functionally similar species, whereby the invading dissimilar alien species exploits resources unused by natives (Crawley et al.1996; Thuiller et al. 2010; 'try-harder' hypothesis).

\section{Methods}

Study area

This study was conducted in the Saint Katherine Protectorate (SKP), South Sinai, Egypt. SKP is located in the arid North African belt and is characterized by a Saharan-Mediterranean climate with extremely dry, hot summers and cold winters. Average rainfall is $57 \mathrm{~mm}$ a year, with average maximum temperatures of $35{ }^{\circ} \mathrm{C}$ and minimum temperatures of $5{ }^{\circ} \mathrm{C}$ (St Katherine Protectorate Management Unit, pers. comm.). The high mountains (1600-2460 m asl) surrounding the town of St Katherine receive higher levels of precipitation, of up to $100 \mathrm{~mm}$ per year (Ayyad et al. 2000). The area includes the highest peaks in Egypt and contains a unique assemblage of natural resources, notably high-altitude ecosystems with surprisingly diverse fauna and flora and with a significant proportion of endemic species. The diversity of both landforms and geologic structures of SKP leads to the differentiation of unique mountainous microhabitats (e.g. wadis, gardens, caves, inter-mountainous roads). SKP encompasses approximately $4350 \mathrm{~km}^{2}$ of largely mountainous terrain in South Sinai, but the studied area was approximately $100-150 \mathrm{~km}^{2}$ in size. Field surveys were carried out during spring and summer seasons from March to July 2018.
Stand and species data

A total of 110 stands of each $10 \mathrm{~m}^{2}$ were arbitrarily placed throughout the locations of alien plant species to cover the entire range of the invaded plant communities within the study area. Only invaded locations with appreciable vegetation (e.g. presence of at least one alien / native plant individual) were selected as stands. Stand size was relatively small $\left(10 \mathrm{~m}^{2}\right)$ due to the generally sparse vegetation cover under the arid conditions. For each stand, we recorded the coordinates and elevation using GPS. In total, 33 alien and 130 native plant species were recorded within the sampled stands, covering a gradient of soil resources. Of the 110 stands, 55 were principally distributed within resource-limited environments (dominated by rocky substrate with limiting soil resources) and 55 were distributed within comparably resource-rich environments, hereafter referred to as 'resource-rich' (moderately rocky sites with availability of soil resources). We excluded 14 stands in resource-rich environments where native plant species richness was almost zero, leaving a total of 96 sites.

Resource-rich environments were mostly dominated by woody alien plant species (e.g. small shrubs/sub-shrubs) with high cover percentage $(70.16 \%)$ compared to woody native plant species (e.g. small shrubs/sub-shrubs, $30.81 \%$ ). In contrast, resource-limited environments were dominated by herbaceous native species (cover $52.72 \%$ ). All plants were identified to species and the number of alien and native individuals per stand was counted ("Appendix": Table 3).

\section{Soil data}

In each stand, soil moisture, soil nitrogen content and organic matter were measured. Soil moisture measurements were taken directly from the field in the early morning with a field hygrometer that measures the volumetric water content in soil. Soil samples (five samples per stand) were collected at random from each stand and air-dried to constant mass, then soil water extracts at 1:5 were prepared for the determination of soil nitrogen and organic matter content. The percentage of organic matter was calculated as the difference between total $\mathrm{C}$ and $\mathrm{CaCO} 3 \%$ (Klute 1986). The total concentration of available nitrogen $(\mathrm{mg} / \mathrm{L})$ was calculated using standard 
methods as outlined in Allen et al. (1974) using a CHN analyser (EA1108, Carlo Erba Instruments).

\section{Functional trait data}

For alien plant species, we measured three key functional traits (plant height from the ground $(\mathrm{cm})$, specific leaf area [SLA, $\left(\mathrm{cm}^{2} / \mathrm{g}\right)$ and the above-ground biomass $(\mathrm{kg})$ ] directly from the field for each alien plant individual. These traits are thought to capture a large part of the ecologically significant differences among species (Westoby 1998) as well as influence resource acquisition and environmental tolerances (Weiher and Keddy 1995). SLA was calculated as the total leaf area (using IMAGEJ software 1.49 version) divided by leaf dry weight (e.g. PérezHarguindeguy et al. 2013). To obtain measurements for above-ground biomass of alien species, we collected leaves and stems destructively from the field, which were then dried in a drying oven (VWR International) at $50{ }^{\circ} \mathrm{C}$ for 3 days, then weighed using a Mettler Toledo ML Series Precision Balance (ML Analytical balance). For native plant species, plant height $(\mathrm{cm})$, number of leaves, leaf area $\left(\mathrm{cm}^{2}\right)$ (drawn in the field then scanned using IMAGEJ software 1.49 version), number of flowers and fruits, were directly measured in the field. These non destructively measured traits were used as predictors to estimate the two destructive traits as response variables, SLA and biomass, through allometric equations (Basuki et al. 2009) as destruction of native biodiversity is strictly forbidden within SKP. We then constructed and validated a series of multivariate regression models using model selection criteria to select the best models of predicting native SLA and biomass within their protected range (see "Appendix": Table 3 and Figs 5, $6)$.

Estimation of the absolute mean functional distance (MFD)

To estimate the functional similarity and dissimilarity among aliens and natives, we measured the mean functional distance (MFD) as the mean weighted pairwise distance of each alien species to the native community (Gallien and Carboni 2017; Carboni et al. 2018). This distance measures the functional differences between aliens and the recipient native community based on the combination of height, SLA and the above-ground biomass. For each alien species, it was calculated using the 'dist' function in R (package 'stats' version 3.5.2) as the 'Euclidean' distance of the alien species' traits to the mean of native species traits in each stand, weighted by their abundance.

\section{Estimation of alien hierarchical distance}

We calculated alien hierarchical distances as the differences in each key functional trait (height, SLA, biomass) between alien plants and the mean trait values of resident native plants within each stand. This hierarchical trait index is used as a proxy to test the relative competitive ability of alien species to native species (Kunstler et al. 2012; Gallien et al. 2017). For example, if the trait difference $\left(t_{A}-t_{N}\right)$ between an alien species $A$ (with trait value $t_{A}$ ) and a native species $N$ (with trait value $t_{N}$ ) is positive, alien species $\mathrm{A}$ is expected to be more competitive than native species $\mathrm{N}$. In this way, we constructed a competition trait hierarchy to test whether alien plants have higher competitive ability (positive hierarchical distances) or lower competitive ability (negative values) than natives or are equally competitive as natives (hierarchical value close to zero) for each trait (i.e. its hierarchical position on each trait gradient (Mayfield and Levine 2010; Kunstler et al. 2012; Gallien et al. 2015). This hierarchical index was calculated for each trait separately.

\section{Multivariate modelling framework}

We constructed a series of mixed-effect models, using species functional traits (height, SLA, biomass), MFD, and the hierarchical distances of height, SLA and biomass as response variables. Soil resource measures (organic matter, nitrogen, soil moisture) were included as explanatory variables, with analyses implemented using "Ime4" (version 1.1-20; Bates et al. 2015). First, the fixed effects explaining functional traits were represented by two-way interactions between species identity (alien/native) and soil variables. Such interaction terms are designed to examine the influence of soil resources on alien and native trait values (e.g. Pollock et al. 2012). Positive species-soil interactions refer to higher values of a soil resource increase the species trait values and vice-versa. A benefit of this modelling approach is that we can visualize the extent of alien and native trait variation for a certain soil 
variable to unravel trait responses to soil resource gradients. Second, the fixed effects explaining MFD and the hierarchical distances were represented by the main effects of the three crossed continuous soil resources.

All response and explanatory variables were centred and standardized with respect to the overall mean and scaled by 1 SD (Schielzeth 2010). All explanatory variables included in the model (soil variables, traits and functional distance) were only weakly correlated with each other (Pearson correlations $<0.6$ ), so that multicollinearity was not an issue.

In all models, we initially included site and stand identities as a random effect, but we found that the variance captured by site and stand identities was very low compared to the residuals. This might be attributed to including species identity in the fixed effects which turned out to be the main factor determining the variability in the studied trait values. Therefore, we simplified the model structure by removing site and stand identities from the random effect structure. Subsequently, we included a taxonomic nested classification (Family/Genus/Species) as a random effect that captured a considerable amount of variance, allowing slope and intercept parameters to account for shared evolutionary relationships among species (Table 1). Full models with all possible structures of the nested random effects and fixed effects were compared to test the potential explanatory power of the fully taxonomic structure of the nested random effect using Akaike's information criterion (AIC). We then tested whether such a structure of random effects effectively accounted for the phylogenetic non-independence among species by testing model residuals for evidence of phylogenetic signal (Revell 2010). For this test, we extracted model residuals and linked them to the corresponding species. Then, we tested for the strength of the phylogenetic signal of these residuals using the function 'phylosig' from 'phytools' (version 0.3-72, (Revell 2012; González-Suárez et al. 2015) and a phylomatic phylogeny including the studies species (aliens/natives). The 'phylosig' function computes the phylogenetic signal in a variable (in our case, model residuals) estimating Blomberg's K (Blomberg et al. 2003).

Finally, we constructed a series of models with all possible combinations of interactions. We calculated the explanatory ability of these models and ranked them by their AIC values (Johnson and Omland 2004). We also evaluated the predictive capacity of each model, by calculating the overall variance explained (conditional $\mathrm{R}^{2}$, following (Nakagawa and Schielzeth 2013) using the package 'MuMIN' (version 1.43.6) (Barton 2016). The best models were filtered according to (1) lower values of AIC, (2) higher values of model probability Akaike's weights (AW) and (3) higher $p$ values of Chi-square test $(p>0.05)$. We checked diagnostic plots (e.g. residuals versus fitted values and observed versus fitted values) for potential outliers and data trends. We plotted normalized residuals against fitted values to identify violation of homogeneity indicated by differences in spread. To overcome the large spread of fitted values, functional traits and MFD were log transformed in order to improve the normality of the error distribution (as determined by inspection of QQ plots), we also verified the normality using the Shapiro-Wilks test. All analyses were conducted in $\mathrm{R}$ v.3.3.1 ( $\mathrm{R}$ Core Team 2018).

\section{Results}

\section{Absolute trait differences among aliens and natives}

Linear mixed effects model comparisons involving functional traits (height, SLA, biomass) as response variables revealed significant trait differences among alien and native plant species, indicating that these differences were mostly explained by availability of soil resources (Fig. 1 and Table 1). Alien plants had significantly higher SLA $\left(p<0.001, \mathrm{R}^{2}=0.89\right)$, height $\left(p<0.01, \quad \mathrm{R}^{2}=0.73\right) \quad$ and biomass $\left(p<0.001, \quad \mathrm{R}^{2}=0.79\right)$ than co-occurring native plants at high resource availability. In contrast, within resource-limited environments, we saw similar trait values in alien and native plants (Table 1 and Fig. 1). First, in high resource availability stands, alien plant species responded positively to increasing soil organic matter and nitrogen (Table 1), but negatively to high soil water content exhibiting high values of aboveground biomass, height and SLA (Fig. 1). Native plant species responded negatively to increases in soil moisture, nitrogen and organic matter and, on average, recorded lower values of above-ground biomass as well as SLA and height when compared to alien species (Table 1). Second, in resource-limited stands, 
Table 1 Average and 95\% confidence intervals (in square brackets) estimates from linear mixed effects models testing the response of alien and native plant species functional traits
(Biomass, height and SLA) to soil resources (organic matter, nitrogen and soil moisture) including the taxonomic variance that was captured by the random effect

\begin{tabular}{|c|c|c|c|c|c|c|c|}
\hline \multirow[t]{4}{*}{ Fixed effects } & \multicolumn{7}{|c|}{ Response variables } \\
\hline & \multicolumn{2}{|c|}{ Biomass (kg) } & \multicolumn{2}{|c|}{ Height $(\mathrm{cm})$} & \multicolumn{2}{|l|}{ SLA $\left(\mathrm{cm}^{2} / \mathrm{g}\right)$} & \multirow{3}{*}{$\begin{array}{l}\text { MFD } \\
\text { Co-efficient } \\
\text { CI [Upper, lower] }\end{array}$} \\
\hline & \multicolumn{2}{|c|}{$\begin{array}{l}\text { Co-efficient } \\
\text { CI [Upper, lower] }\end{array}$} & \multicolumn{2}{|c|}{$\begin{array}{l}\text { Co-efficient } \\
\text { CI [Upper, lower] }\end{array}$} & \multicolumn{2}{|c|}{$\begin{array}{l}\text { Co-efficient } \\
\text { CI [Upper, lower] }\end{array}$} & \\
\hline & Alien & Native & Alien & Native & Alien & Native & \\
\hline Soil moisture $(\%)$ & $\begin{array}{c}-0.07 \\
{[-0.15} \\
0.02]\end{array}$ & $\begin{array}{l}-0.15 * * * \\
{[-0.20} \\
-0.10]\end{array}$ & $\begin{array}{l}0.01 \\
{[-0.07} \\
0.09]\end{array}$ & $\begin{array}{c}-0.06 * \\
{[-0.11} \\
-0.01]\end{array}$ & $\begin{array}{l}0.00 \\
{[-0.05} \\
0.05]\end{array}$ & $\begin{array}{l}-0.13 * * * \\
{[-0.16} \\
-0.09]\end{array}$ & $\begin{array}{l}0.09 * \\
{[0.01,0.16]}\end{array}$ \\
\hline Nitrogen $(\mathrm{mg} / \mathrm{L})$ & $\begin{array}{l}0.10 \\
{[-0.10} \\
0.30]\end{array}$ & $\begin{array}{l}-0.53 * * * \\
{[-0.65} \\
-0.41]\end{array}$ & $\begin{array}{l}0.04 \\
{[-0.05} \\
0.12]\end{array}$ & $\begin{array}{c}-0.01 \\
{[-0.05} \\
0.03]\end{array}$ & $\begin{array}{l}0.22 * * * \\
{[0.17,0.28]}\end{array}$ & $\begin{array}{l}-0.18 * * * \\
{[-0.21} \\
-0.15]\end{array}$ & $\begin{array}{l}0.07 * * \\
{[0.01,0.14]}\end{array}$ \\
\hline $\begin{array}{l}\text { Organic matter (g/ } \\
\mathrm{ml})\end{array}$ & $\begin{array}{l}0.09 \\
{[-0.01} \\
0.18]\end{array}$ & $\begin{array}{l}-0.06 * \\
{[-0.11} \\
-0.01]\end{array}$ & $\begin{array}{l}0.02 \\
{[-0.07} \\
0.11]\end{array}$ & $\begin{array}{c}-0.03 \\
{[-0.08} \\
0.01]\end{array}$ & $\begin{array}{l}0.14 * * * \\
{[0.08,0.20]}\end{array}$ & $\begin{array}{l}-0.09 * * * \\
{[-0.12} \\
-0.06]\end{array}$ & $\begin{array}{l}0.05^{*} \\
{[-0.02,0.12]}\end{array}$ \\
\hline \multicolumn{2}{|l|}{ Random effect } & \multicolumn{2}{|c|}{ Variance/SD } & Variance/SD & \multicolumn{2}{|c|}{ Variance/SD } & Variance/SD \\
\hline \multicolumn{2}{|l|}{ Species/genus/family } & \multicolumn{2}{|l|}{0} & $0.22 / 0.47$ & \multicolumn{2}{|c|}{$0.35 / 0.68$} & 0 \\
\hline \multicolumn{2}{|l|}{ Genus/family } & \multicolumn{2}{|c|}{$0.22 / 0.47$} & $0.36 / 0.68$ & \multicolumn{2}{|l|}{0} & $0.05151 / 0.2270$ \\
\hline \multicolumn{2}{|l|}{ Family } & \multicolumn{2}{|c|}{$0.81 / 0.98$} & $0.14 / 0.37$ & \multicolumn{2}{|c|}{$0.74 / 0.86$} & $0.12102 / 0.3479$ \\
\hline \multicolumn{2}{|l|}{ Residuals } & \multicolumn{2}{|c|}{$0.28 / 0.53$} & $0.25 / 0.51$ & \multicolumn{2}{|c|}{$0.19 / 0.31$} & $0.81219 / 0.9012$ \\
\hline \multicolumn{2}{|l|}{ AIC } & \multicolumn{2}{|c|}{1556.66} & 1554.17 & \multicolumn{2}{|c|}{915.59} & 2206.75 \\
\hline \multicolumn{2}{|l|}{$\mathrm{BIC}$} & \multicolumn{2}{|c|}{1603.60} & 1605.79 & \multicolumn{2}{|c|}{967.18} & 2239.6 \\
\hline \multicolumn{2}{|c|}{$\mathrm{R}^{2}$ (conditional)/R2 (marginal) } & \multicolumn{2}{|c|}{$0.79 / 0.14$} & $0.74 / 0.044$ & \multicolumn{2}{|c|}{$0.89 / 0.041$} & $0.3 / 0.037$ \\
\hline
\end{tabular}

Significant association test $(* * * p<0.001 ; * * p<0.01 ; * p<0.05$.)

aliens and natives tended to be more functionally similar. Both species groups exhibited more similar biomass, height and SLA values with low nitrogen content. However, native plants showed a slight increase in their above-ground biomass response to resource limitation (Fig. 1).

Absolute multi-trait functional distance along the soil resource gradient

Mixed model effects revealed a significant positive relationship between the availability of soil resources and the absolute mean functional distance (MFD) among aliens and natives in richer resource environments (Table 1 and Fig. 2). Such absolute distance increased significantly $(t=2.695, \quad p<0.001$; $t=2.495, \quad p<0.01 ; \quad t=1.660, \quad p<0.01) \quad$ with increasing availability of soil nitrogen, soil moisture and organic matter, respectively. Likewise, resourcelimited environments had a significant negative effect on MFD among aliens and natives (Fig. 2) with more stressful conditions leading to a decline in the mean functional distance. This finding demonstrates that alien plants tend to co-exist with dissimilar native plants in richer resources environments but with more similar native plants under extreme limiting resources.

Alien hierarchical trait distance along the soil resource gradient

On average, there were significant positive relationships between alien hierarchical trait distances and soil resource availability (Table 2 and Fig. 3). Alien plants tended to have positive SLA and biomass hierarchical distances $(t=1.471, p<0.001 ; t=1.416, p<0.05)$, which increased significantly with increasing soil 

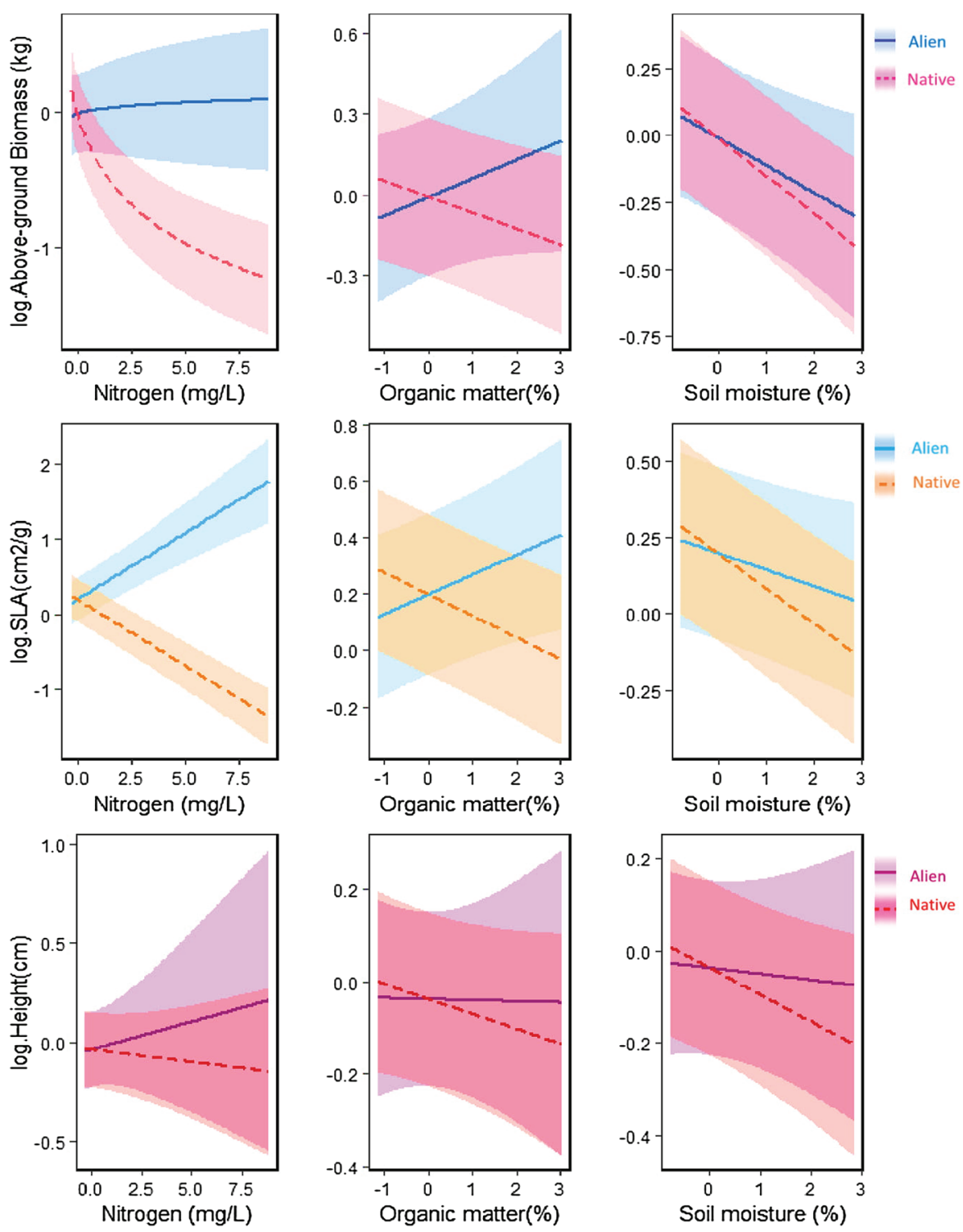

Fig. 1 Showing the trait differences (Above-ground biomassspecific leaf area (SLA) - height) among alien and native plant species in responding to soil resources (nitrogen, organic matter, soil moisture) availability in SKP.Continuous and dashed lines

organic matter content respectively. In other words, alien species with high SLA, height and above-ground biomass values are more competitive than resident native plants particularly in richer organic carbon and nitrogen environments. However, we found a negative range of alien height hierarchical distance $(t=-1.213, p<0.05)$ in limited organic carbon environments. Likewise, alien biomass and SLA hierarchical distances were likely to be around zero

represent the average response of aliens and natives respectively expected by the model with $95 \%$ confidence intervals (shaded areas). All x-axes were scaled/y axes were logged and scaled

in stands with limited soil moisture and nitrogen. These findings revealed that alien species had high functional trait values and tend to be dissimilar from natives in nutrient-rich environments, whilst alien plants tended to be functionally similar or had comparatively equal values of SLA, biomass and height, in such stressful or resource-limited stands (Table 2). 

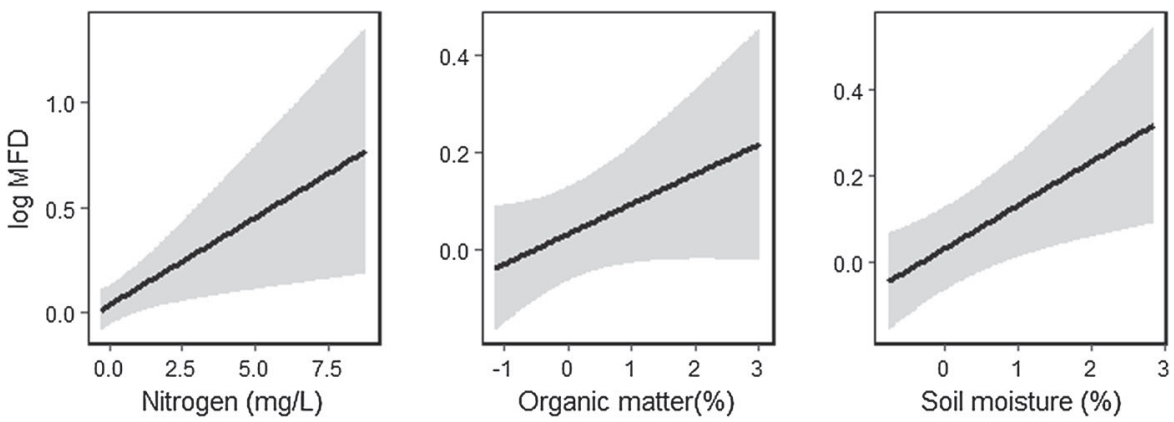

Fig. 2 The response of the mean functional distance (MFD) among aliens and natives to relation to soil resource (organic matter, nitrogen, soil moisture) availability expected by the

model with 95\% confidence intervals (shaded areas). All soil resources were scaled / MFD was logged and scaled

Table 2 Average and 95\% confidence intervals (in square brackets) estimates from multivariate models testing the response of alien hierarchical distances for biomass, SLA and height to soil resource (organic matter, nitrogen, soil

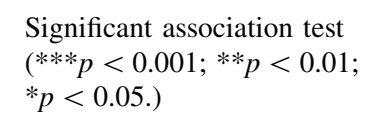

Significant association test $(* * * p<0.001 ; * * p<0.01$; $* p<0.05$.)

\section{Discussion}

Our study demonstrates that alien and native plant species are functionally similar in resource-limited environments, yet functionally dissimilar in comparably resource-rich environments within an arid ecosystem. The finding that alien species were dissimilar to natives and exhibited more acquisitive and competitive trait values (positive hierarchical distances values) than native species in the resource-rich environments partially supports the 'try-harder' hypothesis. However, under limited soil resources, alien and native plants revealed conservative and similar trait values, partially supporting the 'join-thelocals' hypothesis. Moreover, and in support of our expectations, mean functional distance among aliens and natives became greater with increasing resource availability (Fig. 4).
A possible explanation for the functional divergence among alien and native plants in more resource rich environments is likely a divergence in resourceuse strategies caused by differentiation in resource acquisition. For example, it is frequently thought that a higher ability of nutrient acquisition will benefit the alien species and thus promote establishment success, subsequently enhancing their invasiveness (Davis et al. 2000; Dawson et al. 2012). To date, most comparative studies on such environments have found that native species tend to follow a slow-return strategy, while alien species follow a fast-return strategy (Leishman et al. 2008; Penuelas et al. 2010; Ordonez and Olff 2013). Thus, plant species with slow returns on resource investments (possessing lower trait values such as low specific leaf area) are supposed to have high construction costs and low photosynthetic rates. At the opposite extreme, plants with fast returns on resource investments, i.e. higher trait values such as 

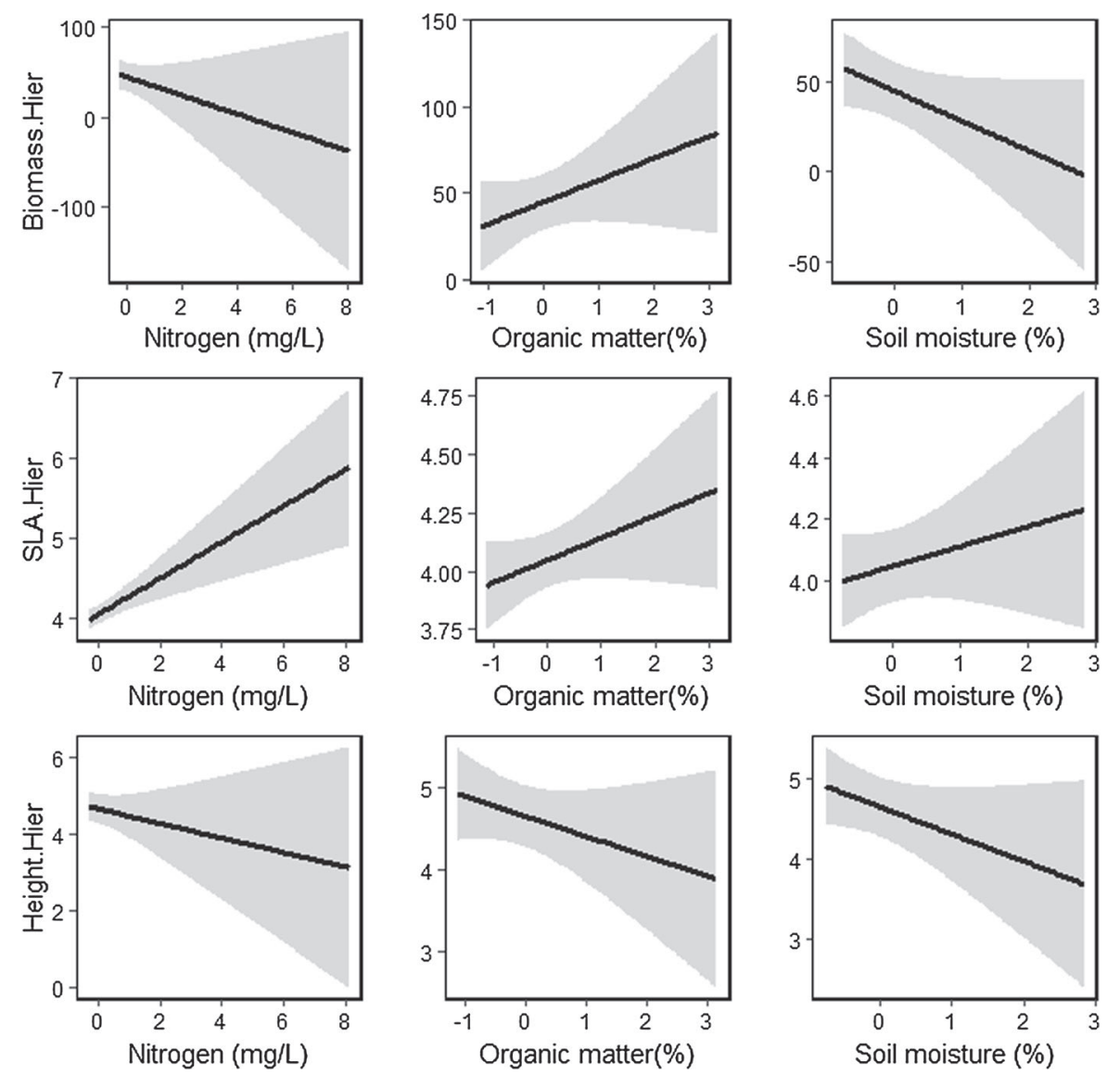

Fig. 3 The alien hierarchical distances for biomass, SLA and height in response to soil resources (organic matter, nitrogen, soil moisture) availability expected by the model with $95 \%$ confidence intervals. All soil variables were scaled

high specific leaf area, are supposed to have higher growth rates (Poorter and Evans 1998;Schieving and Poorter 1999).

Fast-growing alien species are presumably more successful at a global scale than slow-growing species (Grotkopp and Rejmánek 2007; Dawson et al. 2011). Specifically, fast-growing alien species tend to have a greater resource-capture ability (Wright et al. 2004; Rose et al. 2009), which might explain their invasion success. For example, Dawson et al. (2011), assessed the relationship between global invasiveness and the maximum relative growth rate of 105 plant species commonly occurring in the United Kingdom. They found that the maximum relative growth rate of alien species is positively associated with their global invasiveness. In accordance, our study added more evidence that alien plants with exploitative syndromes (tall, with high above-ground biomass and SLA values) were responding positively to soil resources.
These functional attributes come up with an exploitative nutrient-use strategy that is expected to be associated with high resource availability (Laliberté et al. 2012; Dyderski and Jagodziński 2019). Hence, this strategy enables alien plants to capture a large proportion of light resources and conduct high rates of photosynthesis (Gaudet and Keddy 1988; Aerts 1999). This leads to greater assimilation of organic carbon and nitrogen compounds (Westoby 1998; Bullock et al. 2001; Grime 2006) and faster growth rates (Warren and Adams 2001; Onoda et al. 2004; Takashima et al. 2004; Feng et al. 2009). By contrast, native plants showed lower functional trait values (height, SLA and biomass) than aliens and responded negatively to soil resource availability. This is in line with conservative trait syndromes that seek resource conservation rather than acquisition (Lake and Leishman 2004). 


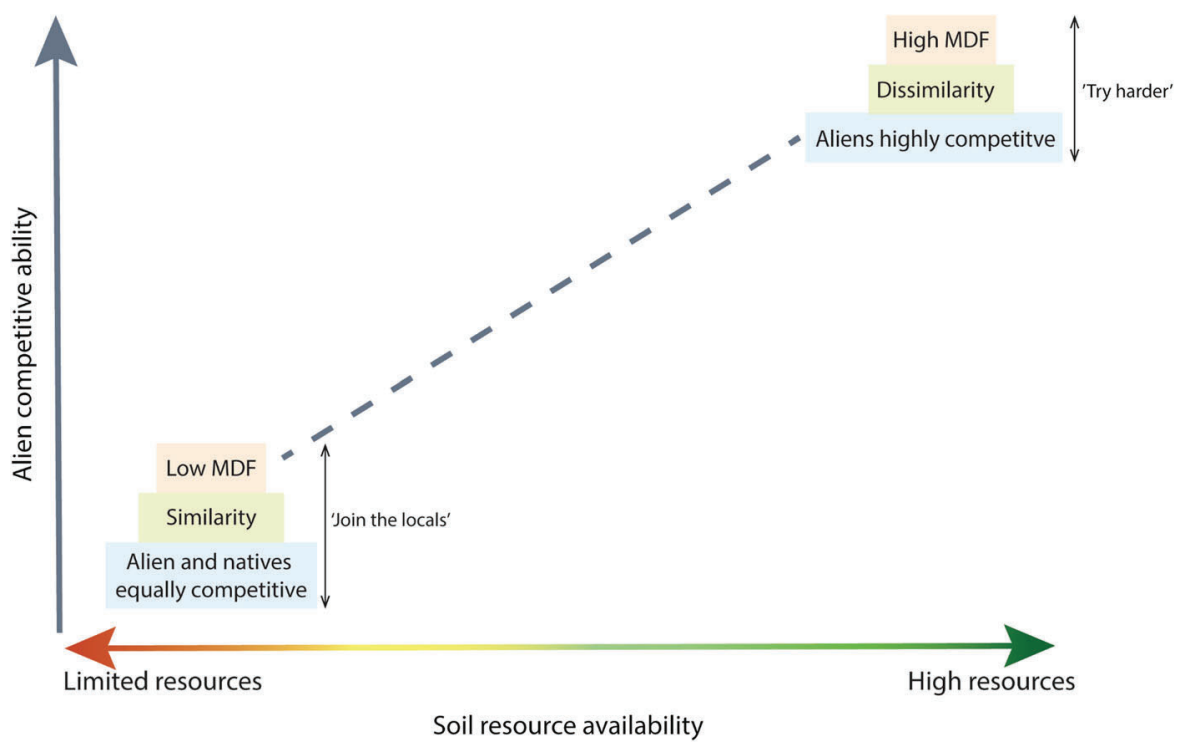

Fig. 4 Hypothetical functional similarity and dissimilarity between alien and native plants in response to soil resource gradients and alien competitive ability. Dashed line indicates the

Functional dissimilarity among aliens and natives in resource-rich environments may also arise from the differences in the competitive abilities of both species groups (Cavender-Bares et al. 2004; Mayfield and Levine 2010; Kunstler et al. 2012). These differences were originally attributed to the superior competitive ability of alien plants to eliminate co-occurring resident native plants that have similar trait values and soil preferences. Therefore, if both species groups compete for different resources, and aliens outcompete resident natives, this should favour aliens that are functionally dissimilar from resident natives to become established (Duncan and Williams 2002; Richardson and Pyšek 2006). In this case, functional dissimilarity cannot be disentangled from competitive exclusion (Gallien et al. 2015).

Likewise, we found that alien and native plants were functionally similar in resource-limited environments and had similar trait values regarding their response to soil resources. Previous studies (e.g. Pyšek et al. 1995, 2005; Prinzing et al. 2002) have suggested that both species groups should be more similar under stressful conditions (van Kleunen et al. 2010; Jauni and Hyvönen 2012) and share analogous simultaneous responses to the limiting environmental resources. For example, Cadotte et al. (2018) suggested that in extreme environments, alien plant species are more hypothesized responses of alien competitive ability and similarity between aliens and natives along gradients of resource availability

likely to interact directly and compete for the same pool of limiting resources. Therefore, alien species should not be so different from natives since the maladaptation to harsh environmental conditions prevents them from becoming established (Thuiller et al. 2010).

There are two factors that have been suggested to explain functional similarity in such environments. First, environmental filtering selects species that can tolerate the extreme environmental conditions (Gallien et al. 2017; Cadotte et al. 2018). Second, competitive filtering, which is supposed to drive similarity among aliens and natives if both species groups compete for the same limiting resources (Mayfield and Levine 2010); only strong competitors with trait values similar to residents will be selected and are expected to survive (Gallien and Carboni 2017). However, we found that resident natives were less conservative species with moderately higher biomass and height values than aliens, indicating they might use a fast-return strategy for resource acquisition when harsh conditions prevail (Leishman et al. 2008; Penuelas et al. 2010; Ordonez and Olff 2013; but see Funk and Vitousek 2007; Dawson et al. 2011). Such a strategy might allow native species to be more tolerant to low-resource conditions and display trait values associated with slow growth, resource-use 
efficiency, high biomass, high tissue construction cost, and long-lived tissues (Chapin III 1980; Vitousek 1982; Craine 2009; Funk et al. 2013). This is in line with predictions of the resource-limitation theory, assuming that plants should allocate higher biomass to structures that help them to acquire more of the most limiting resources (Poorter and Nagel 2000).

Study constraints

We acknowledge some limitations associated with our study, necessitated by constraints working in the Saint Katherine Protectorate. First, our approach of arbitrarily selecting sampling plots may have led to some bias in the analysed community composition (Lep̌s and Hadincová 1992). For example, this approach may have caused a bias toward more resource-rich sites with higher species diversity. However, in contrast to a systematic random method for selecting plots, this approach meant that we ensured representation of the native and alien co-occurring plant communities (Holeksa and Wozniak 2005), necessary to our research aim. Second, given permit restrictions prohibiting the collection of native species, we were unable to obtain trait data requiring destructive methods. For future studies, we thus recommend designing a random sampling strategy for gathering a complete native plant species trait data set (destructive/non-destructive) outside their protected range within similar environmental conditions.

\section{Conclusion}

This study demonstrates that resource availability may explain the presence of contrasting strategies in alien plant species (more acquisitive and competitive/ more conservative) within one single arid ecosystem. The first group, the 'acquisitive and competitive aliens/ dissimilar to natives', are speculated to be more efficient and inhabit disturbed ecosystems with higher resource availability (Leishman et al. 2008, 2010). This is in part because these plants have strategies that correspond to the early successional, fast investment return strategy. They also experienced higher resource costs relative to natives. The other group, the 'conservative aliens/similar to natives', are expected to dominate resource-poor habitats, and have lower invasion success in highly human-modified environments. These plants are expected to follow strategies that place a higher premium on efficient use of resources (conservative strategies) at the expense of rapid growth (Aerts and Chapin III 1999). Thus, future studies should conduct similar studies in different environments to test the generality of our findings. It would further be interesting to test the roles of different nutrient-niches and the acquisition strategies of alien plants for other available nutrients in their introduced and native ranges that might be the foothold of their invasiveness.

Acknowledgements The study was financed by Swiss Government Excellence Scholarship (2018.0730). We are grateful to Caroline Curtis and Giovanni Vimercati (Biology Dept., University of Fribourg) for their comments on earlier drafts of the manuscript.

Authors' Contribution RFE conceived the approach with substantial contributions from SB. IA and AK collected and compiled the datasets. RFE carried out the analyses with advice from RR. RFE wrote the first draft with substantial contributions of SB. AFP helped with the writing of the manuscript. All authors gave final approval for publication.

Funding Funding was provided by Office Fédéral de l'Education et de la Science (ESKAS 2018.07.30).

\section{Appendix: Estimation of native SLA and biomass data using allometric equations}

Because there was no allowance of destructively measuring native biomass and SLA in SKP, we estimated the above-ground biomass and SLA of native plants using allometric equations (Basuki et al. 2009). First, we used four non-destructive traits directly measured in the field per native plant individual. These traits were plant height $(\mathrm{cm})$, leaf area $\left(\mathrm{cm}^{2}\right)$ (drawn in the field then scanned using IMAGEJ), number of leaves and number of flowers and fruits. Second, we constructed series of multivariate regression models to calibrate a predictive model of aliens above-ground biomass and SLA as a function of their height $(\mathrm{cm})$, number of leaves, flowers, fruits and leaf area $\left(\mathrm{cm}^{2}\right)$. Then, we validated the predictive power of this model through model selection criteria using Akaike Information Criterion (AIC) and Akaike Weights (AW) in addition to diagnostic regression plots (e.g. QQ plots) to infer the best regression models. Additionally, we found high correlation 
between the actual observed values of biomass and SLA and the predicted values from the best regression models. Based on this validation, the best fitted model was used to predict natives' biomass and SLA in each stand based on their empirical, field-measured trait values (see Table 3).

Initially, we considered using biomass and SLA data from global databases such as TRY or LEDA, because trait values were found for only 24 native species (out of 133). Likewise, database trait values of these native species that could also be measured non- destructively were much larger compared to the ones that were measured in the field. This difference might indicate the effects of the hyper arid conditions prevailing in Saint-Katherine. We also considered imputing missing values from less than $20 \%$ of the native species as extremely unreliable. Thus, we refrained from using trait values derived from databases and believe that the field - measured trait values (and their allometric derivatives) are more representative and relevant for this study.

Table 3 List of the 130 native and 33 alien plants with mean trait values and SD per species that were recorded in 96 stands

\begin{tabular}{|c|c|c|c|c|c|c|c|c|c|}
\hline \multirow{2}{*}{$\begin{array}{l}\text { Species } \\
\text { Status }\end{array}$} & \multirow[t]{2}{*}{ Family } & \multirow[t]{2}{*}{ Scientific name } & \multirow{2}{*}{$\begin{array}{l}\text { Number of } \\
\text { individuals }\end{array}$} & \multicolumn{2}{|c|}{ Height $(\mathrm{cm})$} & \multicolumn{2}{|c|}{ Biomass (kg) } & \multicolumn{2}{|c|}{ SLA $(\mathrm{cm} 2 / \mathrm{g})$} \\
\hline & & & & Mean & $\mathrm{SD}$ & Mean & $\mathrm{SD}$ & Mean & $\mathrm{SD}$ \\
\hline Alien & Fabaceae & Acacia_saligna & 34 & 463.88 & 268.28 & 75.55 & 64.41 & 42.42 & 12.12 \\
\hline Alien & Agavaceae & Agave_americana & 7 & 131.66 & 51.07 & 2.66 & 0.57 & 3.67 & 0.08 \\
\hline Alien & Liliaceae & Aloe_vera & 16 & 87 & 78.69 & 9 & 7.118 & 4.19 & 0.24 \\
\hline Alien & Amaranthaceae & Amaranthus_caudatus & 45 & 38.33 & 14.84 & 0.33 & 0.33 & 48.49 & 10.88 \\
\hline Alien & Meliaceae & Azadirachta_indica & 9 & 60 & 8.45 & 5 & 3.21 & 238.88 & 45.34 \\
\hline Alien & Chenopodiaceae & Beta_vulgaris & 256 & 42.5 & 31.81 & 35 & 35.35 & 136.35 & 3.96 \\
\hline Alien & Theaceae & Camellia_sinensis & 85 & 38.2 & 34.25 & 1.48 & 1.02 & 102.22 & 19.23 \\
\hline Alien & Casuarinaceae & Casuarina_cunninghamiana & 3 & 700 & 424.26 & 80 & 56.56 & 52.92 & 4.11 \\
\hline Alien & Cactaceae & Cereus_triangularis & 5 & 101 & 140.01 & 27 & 4.24 & & \\
\hline Alien & Iridaceae & Crocus_sativus & 46 & 10 & 5 & 0.05 & 0.045 & 133.82 & 172.79 \\
\hline Alien & Asteraceae & Cynara_cardunculus & 1 & 60 & 0 & 4 & 0 & 32.66 & 0 \\
\hline Alien & Myrtaceae & Eucalyptus_globulus & 55 & 1889.2 & 2864.2 & 144.7 & 147.8 & 39.73 & 12.73 \\
\hline Alien & Verbenaceae & Lantana_camara & 3 & 123 & 34.21 & 5 & 0.62 & 67.5 & 3.76 \\
\hline Alien & Lamiaceae & Mentha_longifolia & 420 & 71.7 & 35.26 & 4.25 & 3.73 & 231.16 & 66.12 \\
\hline Alien & Lamiaceae & Mentha_spicata & 128 & 15.14 & 5.72 & 0.46 & 0.33 & 132.48 & 106.69 \\
\hline Alien & Aizoaceae & Mesembryanthemum_acinaciforme & 10 & 10 & 3.56 & 25 & 5.42 & 297.42 & 38.42 \\
\hline Alien & Moringaceae & Moringa_oleifera & 1 & 90 & 0 & 0.5 & 0 & 147.63 & 0 \\
\hline Alien & Scrophulariaceae & Myoporum_laetum & 3 & 450 & 213.42 & 45 & 9.65 & & \\
\hline Alien & Apocynaceae & Nerium_oleander & 39 & 120.31 & 53.11 & 8.75 & 9.65 & 30.36 & 3.03 \\
\hline Alien & Solanaceae & Nicotiana_rustica & 596 & 60 & 22.73 & 36.75 & 41.72 & 114.08 & 49.39 \\
\hline Alien & Cactaceae & Opuntia_ficus.indica & 2 & 67.5 & 3.53 & 12 & 1.76 & 2.93 & 0.13 \\
\hline Alien & Lamiaceae & Origanum_majorana & 31 & 27 & 13.94 & 0.97 & 0.78 & 126.34 & 28.51 \\
\hline Alien & Papaveraceae & Papaver_somniferum & 12 & 61.16 & 25.65 & 0.24 & 0.21 & 73.43 & 3.1 \\
\hline Alien & Geraniaceae & Pelargonium_peltatum & 4 & 67.5 & 74.24 & 1.5 & 0.7 & 40.24 & 4.77 \\
\hline Alien & Anacardiaceae & Pistacia_lentiscus & 9 & 301.66 & 207.01 & 33.33 & 28.92 & 84.103 & 56.55 \\
\hline Alien & Lamiaceae & Plectranthus_hadiensis & 200 & 60 & 0 & 80 & 20.37 & 140.88 & 76.21 \\
\hline Alien & Anacardiaceae & Rhus_coriaria & 6 & 187.5 & 53.03 & 17.5 & 10.6 & 22.12 & 6.45 \\
\hline Alien & Rosaceae & Rosa_gallica & 15 & 93.6 & 32.76 & 1.6 & 1.02 & 79.94 & 38.28 \\
\hline Alien & Lamiaceae & Rosmarinus_officinalis & 271 & 83.44 & 56.98 & 23.15 & 33.79 & 39.62 & 21.53 \\
\hline Alien & Lamiaceae & Salvia_fruticosa & 93 & 64.35 & 31.57 & 3.99 & 4.6 & 125.39 & 128.6 \\
\hline Alien & Simmondsiaceae & Simmondsia_chinensis & 1 & 190 & 0 & 50 & 0 & 29 & 0 \\
\hline Alien & Cupressaceae & Thuja_orientalis & 1 & 500 & 0 & 30 & 0 & 408.33 & 0 \\
\hline
\end{tabular}


Table 3 continued

\begin{tabular}{|c|c|c|c|c|c|c|c|c|c|}
\hline \multirow{2}{*}{$\begin{array}{l}\text { Species } \\
\text { Status }\end{array}$} & \multirow[t]{2}{*}{ Family } & \multirow[t]{2}{*}{ Scientific name } & \multirow{2}{*}{$\begin{array}{l}\text { Number of } \\
\text { individuals }\end{array}$} & \multicolumn{2}{|c|}{ Height $(\mathrm{cm})$} & \multicolumn{2}{|c|}{ Biomass (kg) } & \multicolumn{2}{|c|}{ SLA (cm2/g) } \\
\hline & & & & Mean & SD & Mean & SD & Mean & SD \\
\hline Alien & Agavaceae & Yucca_gloriosa & 9 & 172.5 & 48.55 & 9.66 & 10.67 & 145.29 & 20.47 \\
\hline Native & Asteraceae & Achillea_fragrantissima & 91 & 53.13 & 27.77 & 1.62 & 0.44 & 23.12 & 78.15 \\
\hline Native & Fabaceae & Alhagi_graecorum & 3 & 40 & 12.43 & 0.67 & 0 & 32.19 & 4.23 \\
\hline Native & Boraginaceae & Alkanna_orientalis & 30 & 21.35 & 19.95 & 8.47 & 28.7 & 27.2 & 102.2 \\
\hline Native & Chenopodiaceae & Anabasis_articulata & 15 & 34 & 10.35 & 1.58 & 0.26 & 2.598 & 0.52 \\
\hline Native & Primulaceae & Anagallis_arvensis & 10 & 10 & 2.45 & 1.2 & 0.04 & 0.129 & 0 \\
\hline Native & Scrophulariaceae & Anarrhinum_pubescens & 10 & 21 & 26.87 & 1.28 & 0.19 & 54.8 & 77 \\
\hline Native & Boraginaceae & Anchusa_milleri & 20 & 7.25 & 2.217 & 1.28 & 0.11 & 0.772 & 0.973 \\
\hline Native & Asteraceae & Artemisia_judaica & 93 & 80.95 & 31.8 & 1.9 & 0.39 & 4.985 & 6.578 \\
\hline Native & Poaceae & Arundo_donax & 40 & 450 & 70.71 & 1.48 & 0.5 & 50.24 & 58.65 \\
\hline Native & Fabaceae & Astragalus_spinosus & 2 & 266.5 & 330.2 & 2.19 & 0 & 5.797 & 6.26 \\
\hline Native & Fabaceae & Astragalus_tribuloides & 16 & 2.667 & 0.816 & 1.15 & 0.49 & 10.93 & 15.33 \\
\hline Native & Asteraceae & Atractylis_carduus & 1 & 4 & 0 & 1.42 & 0 & 7.222 & 0 \\
\hline Native & Poaceae & Avena_barbata & 17 & 76.5 & 9.192 & 1.24 & 0.17 & 4.979 & 3.357 \\
\hline Native & Poaceae & Avena_fatua & 10 & 130 & 70.46 & 1.55 & 0.06 & 1.371 & 0.03 \\
\hline Native & Lamiaceae & Ballota_undulata & 7 & 35.2 & 18.66 & 1.64 & 0.22 & 2.182 & 1 \\
\hline Native & Acanthaceae & Blepharis_attenuata & 1 & 7 & 0 & 1.53 & 0 & 1.101 & 0 \\
\hline Native & Poaceae & Brachypodium_distachyon & 23 & 16.67 & 5.774 & 1.6 & 0.48 & 1.382 & 0.507 \\
\hline Native & Poaceae & Bromus_pectinatus & 24 & 23.25 & 11.32 & 1.86 & 0.16 & 1.365 & 0.871 \\
\hline Native & Resedaceae & Caylusea_hexagyna & 15 & 148.4 & 375.5 & 1.85 & 0.52 & 6.647 & 12.31 \\
\hline Native & Asteraceae & Centaurea_scoparia & 10 & 35.75 & 19.81 & 1.98 & 0.35 & 7.637 & 11.17 \\
\hline Native & Asteraceae & Centaurea_sinaica & 3 & 15 & 5.35 & 1.85 & 0.03 & 2.349 & 0.13 \\
\hline Native & Chenopodiaceae & Chenopodium_album & 45 & 16.67 & 6.853 & 1.17 & 0.6 & 8.444 & 13.93 \\
\hline Native & Chenopodiaceae & Chenopodium_murale & 8 & 15.5 & 0.707 & 0.54 & 0.4 & 17.2 & 24.1 \\
\hline Native & Asteraceae & Chiliadenus_montanus & 13 & 22.5 & 2.887 & 1.52 & 0.73 & 44.34 & 48.59 \\
\hline Native & Cleomiaceae & Cleome_arabica & 30 & 72 & 23.12 & 1.84 & 0.36 & 2.241 & 0.895 \\
\hline Native & Cleomiaceae & Cleome_droserifolia & 3 & 14 & 6.42 & 1.59 & 0.02 & 1.203 & 0.01 \\
\hline Native & Lamiaceae & Clinopodium_serpyllifolium & 1 & 80 & 0 & 1.92 & 0 & 3.418 & 0 \\
\hline Native & Fabaceae & Colutea_istria & 5 & 216.7 & 11.55 & 1.53 & 0.36 & 6.044 & 0.606 \\
\hline Native & Asteraceae & Conyza_aegyptiaca & 22 & 31 & 15.1 & 1.45 & 0.32 & 0.948 & 0.506 \\
\hline Native & Asteraceae & Conyza_bonariensis & 4 & 37 & 4.243 & 1.02 & 0.29 & 0.965 & 0.137 \\
\hline Native & Cucurbitaceae & Cucumis_prophetarum & 2 & 3 & 0.21 & 1.85 & 0.03 & 3.548 & 0.11 \\
\hline Native & Solanaceae & Datura_ferox & 1 & 20 & 0 & 0.61 & 0 & 33.22 & 0 \\
\hline Native & Solanaceae & Datura_stramonium & 1 & 20 & 0 & 0.8 & 0 & 0.842 & 0 \\
\hline Native & Poaceae & Digitaria_sanguinalis & 10 & 60.5 & 7.778 & 1.48 & 0.87 & 1.664 & 0.198 \\
\hline Native & Brassicaceae & Diplotaxis_acris & 39 & 41 & 23.12 & 1.46 & 0.32 & 2.478 & 1.724 \\
\hline Native & Brassicaceae & Diplotaxis_harra & 10 & 17.5 & 10.61 & 1.12 & 0.03 & 0.408 & 0.087 \\
\hline Native & Asteraceae & Echinops_glaberrimus & 2 & 150 & 45.32 & 1.47 & 0.11 & 2.732 & 0.36 \\
\hline Native & Asteraceae & Echinops_spinosus & 5 & 41.5 & 46.36 & 2.1 & 0.51 & 16.36 & 23.26 \\
\hline Native & Geraniaceae & Erodium_laciniatum & 4 & 3.233 & 0.252 & 1.42 & 0.31 & 1.185 & 1.582 \\
\hline Native & Brassicaceae & Eruca_sativa & 4 & 25 & 10.21 & 1.14 & 0.02 & 0.976 & 0.01 \\
\hline Native & Euphorbaiceae & Euphorbia_hirta & 5 & 4 & 1.22 & 1.01 & 0.03 & 0.875 & 0.01 \\
\hline Native & Euphorbaiceae & Euphorbia_obovata & 3 & 10 & 4.65 & 1.44 & 0.02 & 0.373 & 0.02 \\
\hline
\end{tabular}


Table 3 continued

\begin{tabular}{|c|c|c|c|c|c|c|c|c|c|}
\hline \multirow{2}{*}{$\begin{array}{l}\text { Species } \\
\text { Status }\end{array}$} & \multirow[t]{2}{*}{ Family } & \multirow[t]{2}{*}{ Scientific name } & \multirow{2}{*}{$\begin{array}{l}\text { Number of } \\
\text { individuals }\end{array}$} & \multicolumn{2}{|c|}{ Height $(\mathrm{cm})$} & \multicolumn{2}{|c|}{ Biomass (kg) } & \multicolumn{2}{|c|}{ SLA (cm2/g) } \\
\hline & & & & Mean & SD & Mean & SD & Mean & SD \\
\hline Native & Euphorbaiceae & Euphorbia_peplus & 10 & 10 & 4.23 & 2 & 0.26 & 1.052 & 0.01 \\
\hline Native & Euphorbaiceae & Euphorbia_retusa & 7 & 27.67 & 5.033 & 1.78 & 0.08 & 1.965 & 1.19 \\
\hline Native & Zygophyllaceae & Fagonia_arabica & 34 & 16.65 & 10.2 & 8.57 & 28.7 & 2.16 & 1.538 \\
\hline Native & Zygophyllaceae & Fagonia_bovie & 3 & 30 & 0 & 1.53 & 0.08 & 0.966 & 0.911 \\
\hline Native & Zygophyllaceae & Fagonia_bruguieri & 1 & 10 & 0 & 2.93 & 0 & 36.56 & 0 \\
\hline Native & Zygophyllaceae & Fagonia_mollis & 95 & 16.03 & 6.301 & 4.83 & 19.2 & 4.753 & 9.311 \\
\hline Native & Brassicaceae & Farsetia_aegyptia & 2 & 35.5 & 3.536 & 2.13 & 0.75 & 26.14 & 34.39 \\
\hline Native & Moraceae & Ficus_carica & 1 & 100 & 0 & 1.69 & 0 & 4.295 & 0 \\
\hline Native & Moraceae & Ficus_palmata & 6 & 135 & 68.56 & 1.7 & 0.38 & 27.84 & 43.78 \\
\hline Native & Apiaceae & Foeniculum_vulgare & 20 & 62.9 & 60.07 & 1.42 & 0.27 & 23.05 & 44.3 \\
\hline Native & Urticaceae & Forsskaolea_tenacissima & 3 & 128 & 116 & 1.47 & 0.17 & 3.84 & 3.404 \\
\hline Native & Asteraceae & Glebionis_coronaria & 2 & 17 & 4.23 & 1 & 0.01 & 0.707 & 0.01 \\
\hline Native & Chenopodiaceae & Haloxylon_salicornicum & 5 & 50 & 12.24 & 1.96 & 0.02 & 3.374 & 1.41 \\
\hline Native & Boraginaceae & Heliotropium_arbainense & 10 & 12.17 & 2.563 & 1.28 & 0.29 & 20 & 45.74 \\
\hline Native & Poaceae & Hordeum_marinum & 107 & 11.45 & 3.616 & 1.51 & 0.61 & 7.646 & 14.82 \\
\hline Native & Solanaceae & Hyoscyamus_boveanus & 2 & 24.5 & 2.121 & 1.5 & 0.5 & 2.441 & 0.45 \\
\hline Native & Solanaceae & Hyoscyamus_pusillus & 1 & 7 & 0 & 1.66 & 0 & 123.4 & 0 \\
\hline Native & Asteraceae & Iphiona_mucronata & 4 & 15.5 & 3.536 & 1.76 & 0.27 & 2.853 & 0.129 \\
\hline Native & Asteraceae & Iphiona_scabra & 5 & 15 & NA & 1.92 & NA & 1.312 & NA \\
\hline Native & Juncaceae & Juncus_bufonius & 5 & 63 & NA & 1.93 & NA & 2.238 & NA \\
\hline Native & Asteraceae & Lactuca_serriola & 3 & 46 & NA & 1.46 & NA & 3.072 & NA \\
\hline Native & Lamiaceae & Lamium_amplexicaule & 7 & 14 & 3.65 & 0.27 & 0.01 & 34.11 & 14.23 \\
\hline Native & Asteraceae & Launaea_nudicaulis & 2 & 9 & 1.414 & 1.74 & 0.02 & 0.596 & 0.555 \\
\hline Native & Asteraceae & Launaea_spinosa & 5 & 23.33 & 8.505 & 1.5 & 0.12 & 0.903 & 0.433 \\
\hline Native & Lamiaceae & Lavandula_coronopifolia & 1 & 90 & 0 & 1.36 & 0 & 3.827 & 0 \\
\hline Native & Asteraceae & Leysera_leyseroides & 4 & 14 & 0 & 1.75 & 0.08 & 1.911 & 1.212 \\
\hline Native & Plumbaginaceae & Limonium_lobatum & 2 & 10 & NA & 1.47 & NA & 1.992 & NA \\
\hline Native & Plumbaginaceae & Limonium_pruinosum & 7 & 21 & 3.606 & 1.39 & 0.33 & 1.793 & 0.419 \\
\hline Native & Plumbaginaceae & Limonium_sinuatum & 2 & 35 & 10.23 & 1.17 & 0.01 & 3.441 & 2.52 \\
\hline Native & Fabaceae & Lotononis_platycarpa & 1 & 2 & 0 & 1.1 & 0 & 1.628 & 0 \\
\hline Native & Solanaceae & Lycium_shawii & 1 & 110 & 0 & 1.62 & 0 & 4.201 & 0 \\
\hline Native & Malvaceae & Malva_neglecta & 39 & 6.308 & 2.323 & 1.16 & 0.57 & 16.1 & 31.37 \\
\hline Native & Malvaceae & Malva_parviflora & 3 & 12 & 3.14 & 1.23 & 0.04 & 5.679 & 1.01 \\
\hline Native & Brassicaceae & Matthiola_arabica & 17 & 27.67 & 14.11 & 14.9 & 39.4 & 2.632 & 1.14 \\
\hline Native & Brassicaceae & Matthiola_longipetala & 37 & 45.38 & 12.74 & 1.75 & 0.59 & 43.77 & 117.7 \\
\hline Native & Brassicaceae & Morettia_canescens & 3 & 3.25 & 0.354 & 1.79 & 0.27 & 4.842 & 1.655 \\
\hline Native & Solanaceae & Nicotiana_glauca & 1 & 160 & 0 & 1.19 & 0 & 5.504 & 0 \\
\hline Native & Resedaceae & Ochradenus_baccatus & 20 & 92.64 & 30.44 & 1.65 & 0.21 & 3.58 & 1.196 \\
\hline Native & Oleaceae & Olea_europaea & 20 & 137.5 & 59.61 & 1.62 & 0.26 & 12.15 & 25.92 \\
\hline Native & Resedaceae & Oligomeris_linifolia & 3 & 65 & 49.5 & 2.27 & 0.17 & 5.301 & 0.752 \\
\hline Native & Asteraceae & Onopordum_ambiguum & 6 & 83.33 & 47.26 & 1.64 & 0.17 & 3.709 & 0.798 \\
\hline Native & Lamiaceae & Origanum_syriacum & 214 & 21 & 17.18 & 1.81 & 0.8 & 52.22 & 60.96 \\
\hline
\end{tabular}


Table 3 continued

\begin{tabular}{|c|c|c|c|c|c|c|c|c|c|}
\hline \multirow{2}{*}{$\begin{array}{l}\text { Species } \\
\text { Status }\end{array}$} & \multirow[t]{2}{*}{ Family } & \multirow[t]{2}{*}{ Scientific name } & \multirow{2}{*}{$\begin{array}{l}\text { Number of } \\
\text { individuals }\end{array}$} & \multicolumn{2}{|c|}{ Height $(\mathrm{cm})$} & \multicolumn{2}{|c|}{ Biomass (kg) } & \multicolumn{2}{|c|}{ SLA (cm2/g) } \\
\hline & & & & Mean & SD & Mean & SD & Mean & SD \\
\hline Native & Orobanchaceae & Orobanche_palaestina & 3 & 30 & 4.54 & 0.25 & 0.01 & 32.86 & 6.47 \\
\hline Native & Oxalidaceae & Oxalis_corniculata & 10 & 23 & 8.46 & 2.05 & 0.54 & 26.68 & 34.91 \\
\hline Native & Papaveraceae & Papaver_decaisnei & 3 & 30 & 5.36 & 1.45 & 0.01 & 0.931 & 0.02 \\
\hline Native & Zygophyllaceae & Peganum_harmala & 21 & 34.38 & 19.49 & 1.76 & 0.38 & 2.688 & 1.669 \\
\hline Native & Lamiaceae & Phlomis_aurea & 3 & 132.5 & 17.68 & 1.74 & 0.01 & 5.061 & 1.449 \\
\hline Native & Poaceae & Phragmites_australis & 10 & 134 & 45.21 & 1.63 & 0.03 & 107.9 & 35.32 \\
\hline Native & Plantagonaceae & Plantago_sinaica & 9 & 14.67 & 4.041 & 1.57 & 0.11 & 0.754 & 0.322 \\
\hline Native & Portulacaceae & Portulaca_oleracea & 13 & 20 & 5 & 1.17 & 0.17 & 0.955 & 0.697 \\
\hline Native & Asteraceae & Pulicaria_incisa & 7 & 21.67 & 2.887 & 1.5 & 1.12 & 31.9 & 28.25 \\
\hline Native & Asteraceae & Pulicaria_inuloides & 2 & 26.5 & 9.192 & 1.45 & 0.2 & 2.178 & 0.734 \\
\hline Native & Asteraceae & Pulicaria_undulata & 15 & 41.5 & 8.347 & 1.25 & 0.76 & 107.2 & 210.7 \\
\hline Native & Tamaricaceae & Reaumuria_alternifolia & 2 & 16.5 & 2.121 & 2.18 & 0.04 & 2.298 & 2.921 \\
\hline Native & Resedaceae & Reseda_muricata & 9 & 17.75 & 4.031 & 1.6 & 0.21 & 1.196 & 1.257 \\
\hline Native & Resedaceae & Reseda_pruinosa & 5 & 18.33 & 1.155 & 1.87 & 0.05 & 2.351 & 1.882 \\
\hline Native & Fabaceae & Retama_raetam & 10 & 172.2 & 48.61 & 1.61 & 0.53 & 9.9 & 8.156 \\
\hline Native & Rosaceae & Rosa_arabica & 1 & 80 & 0 & 1.27 & 0 & 2.015 & 0 \\
\hline Native & Lamiaceae & Salvia_multicaulis & 14 & 15.5 & 9.983 & 1.66 & 0.27 & 1.933 & 0.79 \\
\hline Native & Asteraceae & Seriphidium_herba.album & 39 & 33.8 & 19.09 & 1.67 & 0.49 & 11.77 & 30.2 \\
\hline Native & Brassicaceae & Sisymbrium_erysimoides & 32 & 13.17 & 5.913 & 1.55 & 0.48 & 4.349 & 7.333 \\
\hline Native & Brassicaceae & Sisymbrium_irio & 6 & 22.5 & 17.68 & 1.48 & 0.3 & 3.691 & 5.056 \\
\hline Native & Solanaceae & Solanum_nigrum & 15 & 41.29 & 15.38 & 1.48 & 0.28 & 16.84 & 40.24 \\
\hline Native & Solanaceae & Solanum_sinaicum & 3 & 58 & 2.828 & 1.45 & 0.2 & 2.373 & 0.281 \\
\hline Native & Solanaceae & Solanum_villosum & 9 & 31 & 3.606 & 1.09 & 0.75 & 13.85 & 20.34 \\
\hline Native & Asteraceae & Sonchus_asper & 3 & 7 & 0 & 0.9 & 0.6 & 11.89 & 18.72 \\
\hline Native & Asteraceae & Sonchus_oleraceus & 35 & 8 & 4.32 & 1.12 & 0.51 & 22.36 & 44.88 \\
\hline Native & Poaceae & Sorghum_virgatum & 12 & 78 & 7.071 & 1.46 & 0.33 & 1.93 & 1.285 \\
\hline Native & Lamiaceae & Stachys_aegyptiaca & 17 & 32.6 & 5.727 & 1.48 & 0.27 & 1.599 & 0.846 \\
\hline Native & Poaceae & Stipa_arabica & 3 & 23 & 0.01 & 1.67 & 0.04 & 3.443 & 0.03 \\
\hline Native & Poaceae & Stipa_capensis & 10 & 23 & 5.67 & 1.14 & 0.02 & 1.008 & 0.01 \\
\hline Native & Poaceae & Stipa_parviflora & 20 & 61.5 & 54.45 & 1.88 & 0.84 & 16.89 & 22.7 \\
\hline Native & Poaceae & Stipagrostis_ciliata & 8 & 13 & 1.414 & 1.91 & 0.12 & 0.195 & 0.262 \\
\hline Native & Chenopodiaceae & Suaeda_aegyptiaca & 4 & 34 & 9.34 & 1.46 & 6.25 & 2.003 & 0.02 \\
\hline Native & Poaceae & Taeniatherum_caput.medusae & 8 & 30.5 & 23.84 & 1.66 & 0.72 & 10.32 & 15.85 \\
\hline Native & Tamaricaceae & Tamarix_aphylla & 1 & 200 & 0 & 1.34 & 0 & 10.84 & 0 \\
\hline Native & Tamaricaceae & Tamarix_nilotica & 4 & 203.8 & 26.89 & 1.85 & 0.21 & 9.057 & 1.725 \\
\hline Native & Asteraceae & Tanacetum_sinaicum & 1 & 250 & 0 & 1.93 & 0 & 8.136 & 0 \\
\hline Native & Lamiaceae & Teucrium_polium & 7 & 21.33 & 3.786 & 1.64 & 0.12 & 4.74 & 4.619 \\
\hline Native & Zygophyllaceae & Tribulus_terrestris & 3 & 3 & 0.062 & 1.23 & 0.02 & 0.885 & 0.01 \\
\hline Native & Boraginaceae & Trichodesma_africanum & 12 & 21 & 6.663 & 1.48 & 0.47 & 8.627 & 12.15 \\
\hline Native & Scrophulariaceae & Verbascum_sinaiticum & 37 & 63.73 & 67.85 & 1.52 & 0.55 & 52.11 & 127.8 \\
\hline Native & Fabaceae & Vicia_monantha & 5 & 10 & 2.43 & 1.95 & 0.02 & 1.381 & 0.01 \\
\hline Native & Solanaceae & Withania_somnifera & 6 & 93.83 & 32.13 & 1.69 & 0.29 & 3.627 & 1.561 \\
\hline
\end{tabular}


Table 3 continued

\begin{tabular}{|c|c|c|c|c|c|c|c|c|c|}
\hline \multirow{2}{*}{$\begin{array}{l}\text { Species } \\
\text { Status }\end{array}$} & \multirow[t]{2}{*}{ Family } & \multirow[t]{2}{*}{ Scientific name } & \multirow{2}{*}{$\begin{array}{l}\text { Number of } \\
\text { individuals }\end{array}$} & \multicolumn{2}{|c|}{ Height $(\mathrm{cm})$} & \multicolumn{2}{|c|}{ Biomass (kg) } & \multicolumn{2}{|c|}{ SLA (cm2/g) } \\
\hline & & & & Mean & $\mathrm{SD}$ & Mean & SD & Mean & SD \\
\hline Native & Brassicaceae & Zilla_spinosa & 82 & 61.63 & 28.97 & 5.25 & 20 & 23.29 & 71.15 \\
\hline Native & Rhamnaceae & Ziziphus_spina.christi & 6 & 95.6 & 41.79 & 1.41 & 0.39 & 7.751 & 10.46 \\
\hline Native & Zygophyllaceae & Zygophyllum_coccineum & 1 & 23 & 0 & 1.86 & 0 & 2.846 & 0 \\
\hline
\end{tabular}



Fig. 5 PCA showing the contribution of the soil resources and functional traits of the two axes of the PCA in explaining the cooccurrence of aliens and natives that resulted in observed overlapped niche (similarity) and differential niche (dissimilarity) 

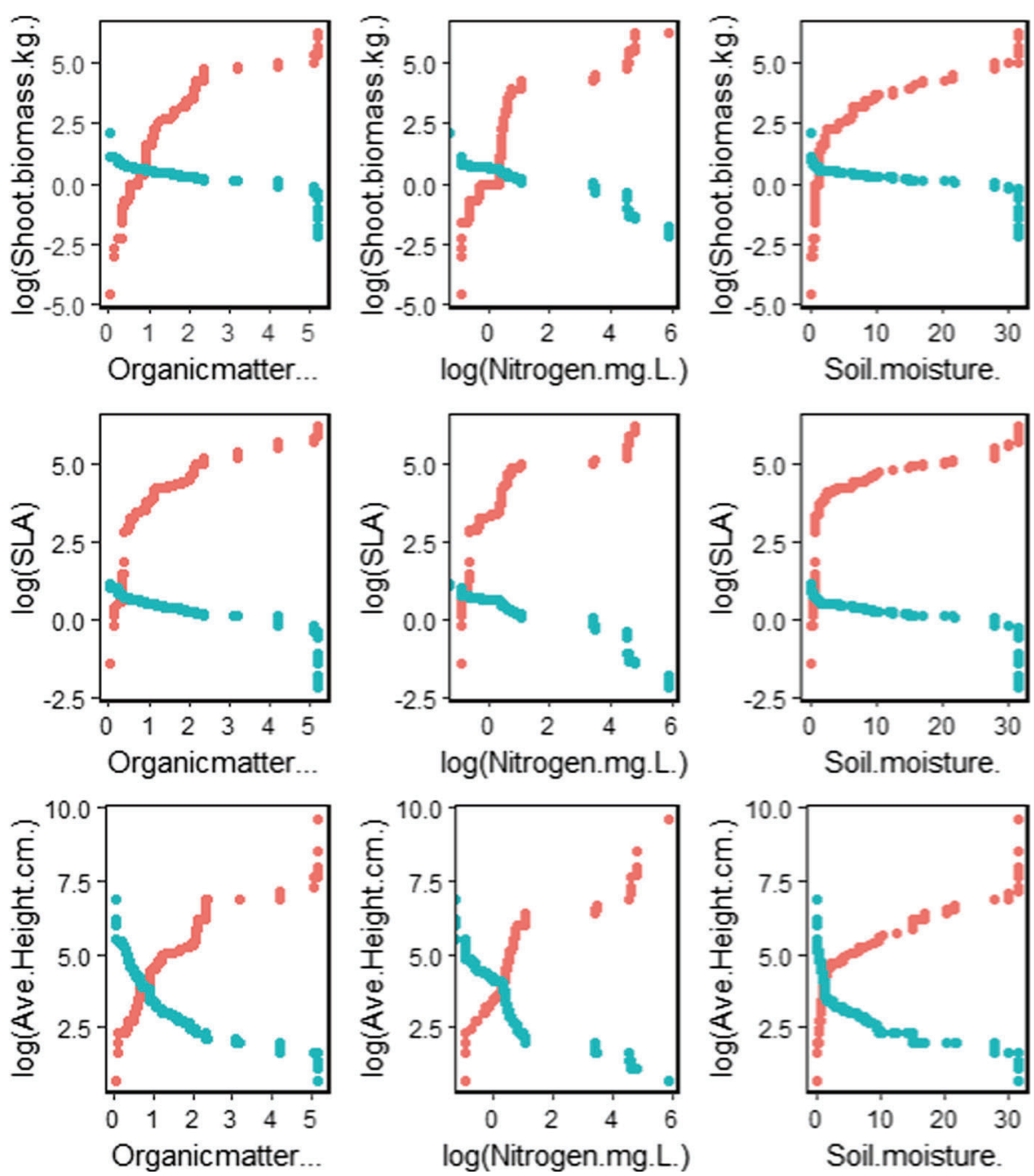

Fig. 6 Observed trait differences (Above-ground biomass-specific leaf area (SLA) — height) among alien (red dots) and native (blue dots) plant species in response to soil resources (nitrogen, organic matter, soil moisture) in SKP

\section{References}

Abrams P (1983) The theory of limiting similarity. Annu Rev Ecol Syst 14:359-376

Aerts R (1999) Interspecific competition in natural plant communities: mechanisms, trade-offs and plant-soil feedbacks. J Exp Bot 50:29-37. https://doi.org/10.1093/jxb/50.330.29 Aerts R, Chapin III FS (1999) The mineral nutrition of wild plants revisited: a re-evaluation of processes and patterns. In: Advances in ecological research, vol 30. Academic Press, pp 1-67

Allen SE, Grimshaw HM, Parkinson JA, Quarmby C (1974) Chemical analysis of ecological materials. Blackwell, Hoboken

Allen CR, Nemec KT, Wardwell DA et al (2013) Predictors of regional establishment success and spread of introduced non-indigenous vertebrates. Glob Ecol Biogeogr 22:889-899
Ayyad MA, Fakhry AM, Moustafa ARA (2000) Plant biodiversity in the Saint Catherine area of the Sinai peninsula, Egypt. Biodivers Conserv 9(2):265-281

Bartoń K (2016) MuMIn: multi-model inference. R package version 1.15.6. https://CRAN.R-project.org/package= MuMIn

Basuki TM, Van Laake PE, Skidmore AK, Hussin YA (2009) Allometric equations for estimating the above-ground biomass in tropical lowland Dipterocarp forests. For Ecol Manag 257:1684-1694

Bates D, Maechler M, Bolker B, Walker S (2015) lme4: linear mixed-effects models using Eigen and S4. R package version 1.1-7. 2014

Blomberg SP, Garland T Jr, Ives AR (2003) Testing for phylogenetic signal in comparative data: behavioral traits are more labile. Evolution 57:717-745 
Blossey B, Notzold R (1995) Evolution of increased competitive ability in invasive nonindigenous plants: a hypothesis. J Ecol 83:887-889. https://doi.org/10.2307/2261425

Blumenthal D (2005) Interrelated causes of plant invasion. Science 310:243-244. https://doi.org/10.1126/science. 1114851

Blumenthal DM (2006) Interactions between resource availability and enemy release in plant invasion. Ecol Lett 9:887-895

Bullock J, Joe F, Mark JS et al (2001) A plant trait analysis of responses to grazing in a long-term experiment. J Appl Ecol 38:253-267. https://doi.org/10.1046/j.1365-2664. 2001.00599.x

Burns JH (2006) Relatedness and environment affect traits associated with invasive and noninvasive introduced Commelinaceae. Ecol Appl 16:1367-1376. https://doi.org/ 10.1890/1051-0761(2006)016\%5b1367:RAEATA\%5d2. $0 . \mathrm{CO} ; 2$

Cadotte MW, Campbell SE, Li S et al (2018) Preadaptation and naturalization of non-native species: Darwin's two fundamental insights into species invasion. Annu Rev Plant Biol 69:661-684. https://doi.org/10.1146/annurev-arplant042817-040339

Carboni M, Calderon-Sanou I, Pollock L et al (2018) Functional traits modulate the response of alien plants along abiotic and biotic gradients. Glob Ecol Biogeogr 27:1173-1185. https://doi.org/10.1111/geb.12775

Catford JA, Jansson R, Nilsson C (2009) Reducing redundancy in invasion ecology by integrating hypotheses into a single theoretical framework. Divers Distrib 15:22-40. https:// doi.org/10.1111/j.1472-4642.2008.00521.x

Cavender-Bares J, Ackerly DD, Baum DA, Bazzaz FA (2004) Phylogenetic overdispersion in Floridian oak communities. Am Nat 163:823-843. https://doi.org/10.1086/386375

Chapin FS III (1980) The mineral nutrition of wild plants. Annu Rev Ecol Syst 11:233-260

Conti L, Block S, Parepa M et al (2018) Functional trait differences and trait plasticity mediate biotic resistance to potential plant invaders. J Ecol 106:1607-1620

Craine JM (2009) Resource strategies of wild plants. Princeton University Press, Princeton

Crawley MJ, Harvey PH, Purvis A (1996) Comparative ecology of the native and alien floras of the British Isles. Philos Trans R Soc B 351:1251-1259. https://doi.org/10.1098/ rstb.1996.0108

Daehler CC (2001) Darwin's naturalization hypothesis revisited. Am Nat 158:324-330

Daehler CC (2003) Performance comparisons of co-occurring native and alien invasive plants: implications for conservation and restoration. Annu Rev Ecol Evol Syst 34:183-211

Davies TJ (2006) Evolutionary ecology: when relatives cannot live together. Evol Ecol 16:R645-R647

Davis MA, Grime JP, Thompson K (2000) Fluctuating resources in plant communities: a general theory of invasibility. J Ecol 88:528-534

Dawson W, Burslem DF, Hulme PE (2011) The comparative importance of species traits and introduction characteristics in tropical plant invasions. Divers Distrib 17:1111-1121
Dawson W, Rohr RP, van Kleunen M, Fischer M (2012) Alien plant species with a wider global distribution are better able to capitalize on increased resource availability. New Phytol 194:859-867

Duncan RP, Williams PA (2002) Ecology: Darwin's naturalization hypothesis challenged. Nature 417:608

Dyderski MK, Jagodziński AM (2019) Functional traits of acquisitive invasive woody species differ from conservative invasive and native species. NeoBiota 41:91-113. https://doi.org/10.3897/neobiota.41.31908

Feng Y-L, Lei Y-B, Wang R-F et al (2009) Evolutionary tradeoffs for nitrogen allocation to photosynthesis versus cell walls in an invasive plant. Proc Natl Acad Sci USA 106:1853-1856

Funk JL, Vitousek PM (2007) Resource-use efficiency and plant invasion in low-resource systems. Nature 446:1079-1081. https://doi.org/10.1038/nature05719

Funk JL, Cleland EE, Suding KN, Zavaleta ES (2008) Restoration through reassembly: plant traits and invasion resistance. Trends Ecol Evol 23:695-703

Funk JL, Glenwinkel LA, Sack L (2013) Differential allocation to photosynthetic and non-photosynthetic nitrogen fractions among native and invasive species. PLoS ONE 8:e64502

Funk JL, Standish RJ, Stock WD, Valladares F (2016) Plant functional traits of dominant native and invasive species in mediterranean-climate ecosystems. Ecology 97:75-83

Gallien L, Carboni M (2017) The community ecology of invasive species: where are we and what's next? Ecography 40:335-352. https://doi.org/10.1111/ecog.02446

Gallien L, Mazel F, Lavergne S et al (2015) Contrasting the effects of environment, dispersal and biotic interactions to explain the distribution of invasive plants in alpine communities. Biol Invasions 17:1407-1423. https://doi.org/10. 1007/s10530-014-0803-1

Gallien L, Zimmermann NE, Levine JM, Adler PB (2017) The effects of intransitive competition on coexistence. Ecol Lett 20:791-800

Gaudet CL, Keddy PA (1988) A comparative approach to predicting competitive ability from plant traits. Nature 334:242. https://doi.org/10.1038/334242a0

González AL, Kominoski JS, Danger M et al (2010) Can ecological stoichiometry help explain patterns of biological invasions? Oikos 119:779-790

González-Suárez M, Bacher S, Jeschke JM (2015) Intraspecific trait variation is correlated with establishment success of alien mammals. Am Nat 185:737-746. https://doi.org/10. $1086 / 681105$

Grime JP (2006) Plant strategies, vegetation processes, and ecosystem properties. Wiley, Hoboken

Grotkopp E, Rejmánek M (2007) High seedling relative growth rate and specific leaf area are traits of invasive species: phylogenetically independent contrasts of woody angiosperms. Am J Bot 94:526-532

Heberling JM, Fridley JD (2013) Resource-use strategies of native and invasive plants in Eastern North American forests. New Phytol 200:523-533

Holeksa J, Woźniak G (2005) Biased vegetation patterns and detection of vegetation changes using phytosociological databases: a case study in the forests of the Babia Góra 
National Park (the West Carpathians, Poland). Phytocoenologia 35(1):1-18

Jauni M, Hyvönen T (2012) Interactions between alien plant species traits and habitat characteristics in agricultural landscapes in Finland. Biol Invasions 14:47-63. https:// doi.org/10.1007/s10530-011-0058-Z

Johnson JB, Omland KS (2004) Model selection in ecology and evolution. Trends Ecol Evol 19:101-108. https://doi.org/ $10.1016 / j$.tree.2003.10.013

Kembel SW, Hubbell SP (2006) The phylogenetic structure of a neotropical forest tree community. Ecology 87:S86-S99

Klute A (1986) Methods of soil analysis. No 9 Part 1, physical and mineralogical methods. American Society of Agronomy Madison, Wisconsin

Kunstler G, Lavergne S, Courbaud B et al (2012) Competitive interactions between forest trees are driven by species' trait hierarchy, not phylogenetic or functional similarity: implications for forest community assembly. Ecol Lett 15:831840. https://doi.org/10.1111/j.1461-0248.2012.01803.x

Lake JC, Leishman MR (2004) Invasion success of exotic plants in natural ecosystems: the role of disturbance, plant attributes and freedom from herbivores. Biol Conserv 117:215226. https://doi.org/10.1016/S0006-3207(03)00294-5

Laliberté E, Shipley B, Norton DA, Scott D (2012) Which plant traits determine abundance under long-term shifts in soil resource availability and grazing intensity? J Ecol 100:662-677

Leffler AJ, James JJ, Monaco TA, Sheley RL (2014) A new perspective on trait differences between native and invasive exotic plants. Ecology 95:298-305. https://doi.org/10. 1890/13-0102.1

Leishman MR, Thomson VP (2005) Experimental evidence for the effects of additional water, nutrients and physical disturbance on invasive plants in low fertility Hawkesbury Sandstone soils, Sydney, Australia. J Ecol 93:38-49. https://doi.org/10.1111/j.1365-2745.2004.00938.x

Leishman MR, Haslehurst T, Ares A, Baruch Z (2008) Leaf trait relationships of native and invasive plants: communityand global-scale comparisons. New Phytol. https://doi.org/ 10.1111/j.1469-8137.2007.02189.x

Leishman MR, Thomson VP, Cooke J (2010) Native and exotic invasive plants have fundamentally similar carbon capture strategies: leaf trait relationships of natives and exotic invasives. J Ecol 98:28-42. https://doi.org/10.1111/j.13652745.2009.01608.x

Lepš J, Hadincová V (1992) How reliable are our vegetation analyses? J Veg Sci 3(1):119-124

Li S, Cadotte MW, Meiners SJ et al (2015) The effects of phylogenetic relatedness on invasion success and impact: deconstructing Darwin's naturalisation conundrum. Ecol Lett 18:1285-1292. https://doi.org/10.1111/ele.12522

Macarthur R, Levins R (1967) The limiting similarity, convergence, and divergence of coexisting species. Am Nat 101:377-385. https://doi.org/10.1086/282505

MacDougall AS, Gilbert B, Levine JM (2009) Plant invasions and the niche. J Ecol 97:609-615. https://doi.org/10.1111/ j.1365-2745.2009.01514.x

Maitner BS, Rudgers JA, Dunham AE, Whitney KD (2012) Patterns of bird invasion are consistent with environmental filtering. Ecography 35:614-623. https://doi.org/10.1111/j. 1600-0587.2011.07176.x
Mayfield MM, Levine JM (2010) Opposing effects of competitive exclusion on the phylogenetic structure of communities: phylogeny and coexistence. Ecol Lett 13:1085-1093. https:// doi.org/10.1111/j.1461-0248.2010.01509.x

Nakagawa S, Schielzeth H (2013) A general and simple method for obtaining R2 from generalized linear mixed-effects models. Methods Ecol Evol 4:133-142

Onoda Y, Hikosaka K, Hirose T (2004) Allocation of nitrogen to cell walls decreases photosynthetic nitrogen-use efficiency. Funct Ecol 18:419-425. https://doi.org/10.1111/j. 0269-8463.2004.00847.x

Ordonez A, Olff H (2013) Do alien plant species profit more from high resource supply than natives? A trait-based analysis: Alien-native leaf trait differences. Glob Ecol Biogeogr 22:648-658. https://doi.org/10.1111/geb.12019

Park DS, Potter D (2015) A reciprocal test of Darwin's naturalization hypothesis in two Mediterranean-climate regions. Glob Ecol Biogeogr 24:1049-1058. https://doi. org/10.1111/geb.12352

Penuelas J, Sardans J, Llusià J et al (2010) Faster returns on 'leaf economics' and different biogeochemical niche in invasive compared with native plant species. Glob Change Biol 16:2171-2185. https://doi.org/10.1111/j.1365-2486.2009. 02054.x

Pérez-Harguindeguy N, Diaz S, Gamier E et al (2013) New handbook for stand-ardised measurement of plant functional traits worldwide. Aust J Bot 61:167-234

Pollock LJ, Morris WK, Vesk PA (2012) The role of functional traits in species distributions revealed through a hierarchical model. Ecography 35:716-725. https://doi.org/10. 1111/j.1600-0587.2011.07085.x

Poorter H, Evans JR (1998) Photosynthetic nitrogen-use efficiency of species that differ inherently in specific leaf area. Oecologia 116:26-37. https://doi.org/10.1007/s004420050 560

Poorter H, Nagel O (2000) The role of biomass allocation in the growth response of plants to different levels of light, $\mathrm{CO} 2$, nutrients and water: a quantitative review. Funct Plant Biol 27:1191. https://doi.org/10.1071/pp99173 co

Prinzing A, Durka W, Klotz S, Brandl R (2002) Which species become aliens? Evol Ecol Res 4:385-405

Pyšek P, Richardson DM (2007) Traits associated with invasiveness in alien plants: where do we stand? In: Nentwig W (ed) Biological invasions. Springer, Berlin, pp 97-125

Pyšek P, Prach K, Smilauer P (1995) Relating invasion success to plant traits: an analysis of the Czech alien flora. In: Pyšek P, Prach K, Rejmánek M, Wade M (eds) Plant invasions: general aspects and special problems. SPB Academic Publishers, Amsterdam, pp 39-60

Pyšek P, Jarošík V, Chytrý M et al (2005) Alien plants in temperate weed communities: prehistoric and recent invaders occupy different habitats. Ecology 86:772-785. https://doi. org/10.1890/04-0012

R Core Team (2018) R: a language and environment for statistical computing. R Foundation for Statistical Computing, Vienna, Austria. https://www.R-project.org/

Rejmánek M, Richardson DM, Pyšek P (2005) Plant invasions and invasibility of plant communities. Veg Ecol 20:332-355 
Revell LJ (2010) Phylogenetic signal and linear regression on species data. Methods Ecol Evol 1:319-329. https://doi. org/10.1111/j.2041-210X.2010.00044.x

Revell LJ (2012) Phytools: an R package for phylogenetic comparative biology (and other things). Methods Ecol Evol 3:217-223. https://doi.org/10.1111/j.2041-210X.2011. 00169. $\mathrm{x}$

Richardson DM, Pyšek P (2006) Plant invasions: merging the concepts of species invasiveness and community invasibility. Prog Phys Geogr 30:409-431

Rose KE, Atkinson RL, Turnbull LA, Rees M (2009) The costs and benefits of fast living. Ecol Lett 12:1379-1384

Schielzeth H (2010) Simple means to improve the interpretability of regression coefficients. Methods Ecol Evol 1:103-113. https://doi.org/10.1111/j.2041-210X.2010. 00012. $\mathrm{X}$

Schieving F, Poorter H (1999) Carbon gain in a multispecies canopy: the role of specific leaf area and photosynthetic nitrogen-use efficiency in the tragedy of the commons. New Phytol 143(1):201-211. https://doi.org/10.1046/j. 1469-8137.1999.00431.x

Takashima T, Hikosaka K, Hirose T (2004) Photosynthesis or persistence: nitrogen allocation in leaves of evergreen and deciduous Quercus species. Plant, Cell Environ 27:10471054. https://doi.org/10.1111/j.1365-3040.2004.01209.x

Tecco PA, DÃ-az S, Cabido M, Urcelay C (2010) Functional traits of alien plants across contrasting climatic and landuse regimes: do aliens join the locals or try harder than them? Alien traits across climates and land uses. J Ecol 98:17-27. https://doi.org/10.1111/j.1365-2745.2009.01592.x

Tecco PA, Urcelay C, Díaz S et al (2013) Contrasting functional trait syndromes underlay woody alien success in the same ecosystem: contrasting syndromes among coexisting aliens. Aust Ecol 38:443-451. https://doi.org/10.1111/j. 1442-9993.2012.02428.x

Thuiller W, Gallien L, Boulangeat I et al (2010) Resolving Darwin's naturalization conundrum: a quest for evidence. Divers Distrib 16:461-475. https://doi.org/10.1111/j.14724642.2010.00645.x

van Kleunen M, Weber E, Fischer M (2010) A meta-analysis of trait differences between invasive and non-invasive plant species. Ecol Lett 13:235-245. https://doi.org/10.1111/j. 1461-0248.2009.01418.x

Vitousek P (1982) Nutrient cycling and nutrient use efficiency. Am Nat 119:553-572. https://doi.org/10.1086/283931

Warren CR, Adams MA (2001) Distribution of N, Rubisco and photosynthesis in Pinus pinaster and acclimation to light. Plant, Cell Environ 24:597-609

Weiher E, Keddy PA (1995) Assembly rules, null models, and trait dispersion: new questions from old patterns. Oikos 74(1):159-164

Westoby M (1998) A leaf-height-seed (LHS) plant ecology strategy scheme. Plant Soil 199:213-227

Westoby M, Falster DS, Moles AT et al (2002) Plant ecological strategies: some leading dimensions of variation between species. Annu Rev Ecol Syst 33:125-159. https://doi.org/ 10.1146/annurev.ecolsys.33.010802.150452

Wright IJ, Reich PB, Westoby M et al (2004) The worldwide leaf economics spectrum. Nature 428:821. https://doi.org/ 10.1038/nature02403

Publisher's Note Springer Nature remains neutral with regard to jurisdictional claims in published maps and institutional affiliations. 